\title{
The Effect of Internal and External Factors of Banking to the SMEs Financing for BPRS in Indonesia
}

\author{
Jaenal Effendi, Nurkholis Yasmin \\ Department of Sharia Economics Bogor Agricultural University \\ Jl. Raya Darmaga Kampus IPB Darmaga Bogor, 16680, Indonesia
}

\begin{tabular}{|c|c|}
\hline \multirow{6}{*}{$\begin{array}{l}\text { Keywords: } \\
\text { BPRS; Internal } \\
\text { Factors; External } \\
\text { Factors; SMEs } \\
\text { Financing; VECM }\end{array}$} & ABSTRACT \\
\hline & Small and Medium Enterprises had a strategic role in economic growth. One of the main \\
\hline & problems faced by SMEs in Indonesia was the limited financial capital and access to \\
\hline & finance. Islamic Rural Banks (BPRS) could play a significant role in providing financing \\
\hline & for the development of the real sector through SMEs. This study aimed to analyze the \\
\hline & influence of internal and external factors of banking to the SMEs financing for BPRS in \\
\hline \multirow{6}{*}{$\begin{array}{l}\text { JEL Classification: } \\
\text { G21, G31, L32, R51 }\end{array}$} & Indonesia 2011-2016 periods using the Vector Error Correction Model (VECM) method. In \\
\hline & the long-term of VECM estimation result showed that third party funds, FDR, inflation, \\
\hline & and IPI had a significant positive effect on SMEs financing, while BOPO, NPF, ERP, and \\
\hline & $\begin{array}{l}\text { BSBIS variables negatively affected SMEs financing. This study recommended the impor- } \\
\text { tance of increasing the proportion of SMEs financing in line with the increase in the }\end{array}$ \\
\hline & $\begin{array}{l}\text { number of third party funds and putting more funds in the real sector than in the mon- } \\
\text { etary sector. }\end{array}$ \\
\hline & ABSTRAK \\
\hline \multirow{11}{*}{$\begin{array}{l}\text { Kata Kunci: } \\
\text { BPRS; Faktor } \\
\text { Internal; Faktor } \\
\text { Eksternal; } \\
\text { Pembiayaan UKM; } \\
\text { VECM }\end{array}$} & Usaha Kecil dan Menengah memiliki peran strategis dalam pertumbuhan ekonomi. Salah satu \\
\hline & problematika utama yang dihadapi oleh UKM di Indonesia adalah keterbatasan modal dan akses \\
\hline & finansial. Bank Pembiayaan Rakyat Syariah dapat memainkan peran yang signifikan dalam \\
\hline & menyediakan pembiayaan bagi pembangunan sektor riil melalui UKM. Penelitian ini bertujuan \\
\hline & untuk menganalisis pengaruh faktor internal dan eksternal perbankan terhadap pembiayaan UKM \\
\hline & pada BPRS di Indonesia periode 2011-2016 dengan menggunakan metode Vector Error Correc- \\
\hline & tion Model (VECM). Pada jangka panjang hasil estimasi VECM menunjukkan bahwa DPK, \\
\hline & FDR, inflasi, dan IPI berpengaruh positif secara signifikan terhadap pembiayaan UKM, sedangkan \\
\hline & variabel BOPO, NPF, ERP, dan BSBIS berpengaruh negatif terhadap pembiayaan UKM. Penelitian \\
\hline & ini merekomendasikan akan pentingnya peningkatan proporsi pembiayaan UKM seiring dengan \\
\hline & $\begin{array}{l}\text { peningkatan jumlah dana pihak ketiga dan lebih menempatkan dana yang terhimpun pada sektor } \\
\text { riil dibandingkan pada sektor moneter. }\end{array}$ \\
\hline
\end{tabular}

$\triangle$ Corresponding Author:

Nurkholis Yasmin: Telp. +6285779913880

E-mail: ny.nurkholisyasmin@gmail.com

ISSN:2443-2687 (Online) ISSN:1410-8089 (Print) 


\section{The Effect of Internal and External Factors of Banking to the Smes Financing for BPRS in Indonesia}

Jaenal Effendi, Nurkholis Yasmin

The role of the real sector in the Indonesian economy can be illustrated by the development of Small and Medium Enterprises (SMEs). According to data from the Ministry of Cooperatives and Small and Medium Enterprises, the number of SMEs in Indonesia in 2015 is 59.26 million business units of all types of business in Indonesia or 99.99 percent of the total business units in Indonesia. The SMEs sector is also become a business unit that absorbed 123.23 million labours or 96.71 percent in 2015 and has grown 25.44 percent of total employment during 2011-2015. In addition, SMEs also contribute greatly to Gross Domestic Product (GDP), it can be seen that the contribution of SMEs in 2015 amounted to IDR1,655.43 trillion, has increased 29.07 percent from 2011. It indicates that SMEs have great potential in improving economic growth, productivity, and competitiveness of Indonesian products.

Based on the lesson learned from the 1998 monetary crisis experienced by Indonesia, SMEs proved to have flexibility and toughness and able to support Indonesia's economy so that eventually Indonesia's economy can survive (Kara, 2013). Many other empirical evidences that show the magnitude of the durability of SMEs in facing crisis situations among others is influenced by the characteristics that have the ability to adapt to economic condition changes. For example, in the incident of economic crisis that causes the formal sector to lay off workers, make many people unemployed so that many of them enter the informal sector by making small-scale enterprises (Partomo \& Soejoedono, 2002). In addition, SMEs are not too dependent on large capital and external loans in the form of dollar exchange rate (Kemendag, 2013).

Beik \& Arsyianti (2015) explained that the most important constraints are the limited capital and access from financial institution sources, particularly access to banking. According to BPS (2015) around 60-70 percent of all sectors of SMEs do not have access to financing through banking. This is an opportunity for financial institutions, especially banking to meet the needs of SMEs capital. One of sharia financial institutions that can be an alternative source of capital for SMEs is the Sharia Rural Bank (BPRS). The main focus of BPRS business on the establishment and development of SMEs by providing capital for non-consumer credit businesses. In accordance with the characteristics of SMEs that according to Tambunan (2009) generally can be said that the motivation of SMEs entrepreneurs are more diverse and business oriented than micro entrepreneurs. The advantage of BPRS from other types of banking is that BPRS is a legitimate institution and can provide services with a wider range, because the main activities of sharia banking is to distribute financing, meet the capital of deficit units, especially financing to the real sector. According to Ascarya \& Yumanita (2014), the profit sharing pattern that is the essence of sharia financing is more suitable in activating the real sector because it increases direct relationship and risk sharing between investor and entrepreneur. The concept of Islam is to maintain the balance between the real sector and the monetary sector, so that the growth of financing will not be separated from the growth of the real sector which it financed. The distribution of financing is in accordance with the words of Allah in the Qur'an Surah Al Hasyr $7^{\text {th }}$ verse which means "...that the treasure is not just circulated among the wealth of the rich alone between you...".

Based on data obtained from the statistics of sharia banking issued by the Financial Services Authority (OJK), in 2016 the financing distributed by BPRS for the SMEs sector is IDR3,52 trillion or 55.99 percent of total financing, meanwhile nonSMEs financing is IDR2,77 trillion or 44.01 percent of the total financing indicating that the fund disbursement of BPRS for the SMEs sector is still larger than the non-SMEs sector. Based on the quarterly report $(\mathrm{OJK}, 2016)$ in terms of financing, 


\section{Jurnal Keuangan dan Perbankan | PERBANKAN}

Vol. 21, No. 3, Juli 2017: 498-514

the performance of BPRS is better than conventional BPR, as seen from the growth of financing from 2015-2016, BPRS increased 6.03 percent meanwhile the conventional BPR only 2.60 percent. It indicates that the growth of BPRS financing for SMEs increases every year, which means that the need for SMEs to BPRS also increases.

One factor of the increasing the total financing provided by the BPRS is the increase in the collection of funds derived from the community (third party funds), beside the sources of funds that derived from core capital and other institutions. Third party funds collected by BPRS are increasing every year until December 2016 and reach IDR5,8 trillion. It indicates that public trust is increasing in terms of saving funds in BPRS. However, together with the increase of third party funds which has been collected by BPRS has not been followed by the ratio of financing for the SMEs sector to total financing. The ratio of SMEs financing tends to decline in the period of July 2015 by 59.32 percent and reach the lowest point on November 2016 as 53.08 percent. However, in terms of business units, the number of SMEs every year is increasing. It indicates that the share of financing for SMEs sector in BPRS is not maximal yet or still relatively small.

This research will analyze the factors affecting SMEs financing in BPRS in Indonesia. The factors studied consist of internal and external banking. The internal factor in this study is the performance of BPRS including financial ratios, while the external factors are syariah monetary instrument and macroeconomic condition.

Research on the influence of internal and external factors of banking on SMEs financing in BPRS in Indonesia has not much done yet. The research on SMEs financing is done by Ramadhan \& Beik (2013) entitled Analysis of the Impact of Islamic and Conventional Monetary Instruments towards Financing of Micro, Small and Medium Enterprises Sector in Indonesia, using the Vector
Error Correction Model (VECM) method. The model used in this study is divided into 2, there are the financing of SMEs through conventional banking and sharia banking. The results showed that SBI and SBIS had a significant influence on the funds distribution to the sector of SMEs, both from the sharia and conventional banking. In addition, the financing of SMEs through sharia banking is faster and more stable compared to SMEs credit of conventional banking in the incident of monetary crisis. Then Mardani (2016) who analyzed the factors that affect financing sharia banking for SMEs sector in Indonesia using panel data regression method. The results showed that the variables affecting the SMEs sector financing positively significant were DPK, FDR, and BSBIS. Meanwhile the variables that effect negatively significant were CAR, NPF, and BOPO.

There are also several studies that analyze the financing of sharia banking to the economic sector. A study of the financing provided to the construction sector by sharia banking in Indonesia has been done by Kusumawati (2013). The variables used consist of banking performance, rate of return, macroeconomic condition, and monetary instruments using VECM method. The results showed that the shocks on FDR, SBI interest rate, IPI, inflation, and ERP variables will be positively responded by the financing ratio of the construction sector. Meanwhile the shocks on variables of DPK, SBK, NPF, SBIS bonus, and placement of funds in PUAS will be responded negatively by the ratio of financing construction sector. The research conducted by Zulhidia (2015) who examined the factors that affect the amount of financing the processing industry sector in BPRS in Indonesia by VECM method. The results showed that the variables of Industrial Production Index (IPI), DPK, and SBK positively affect, while inflation, NPF, and ERP negatively affect financing to the manufacturing sector. 


\section{The Effect of Internal and External Factors of Banking to the Smes Financing for BPRS in Indonesia}

Jaenal Effendi, Nurkholis Yasmin

Research on the factors which influence the amount of financing of sharia banking in Indonesia has been done by Adzimatinur, Hartoyo, \& Wiliasih (2014). The method used is VECM. The results showed that the variables of profit sharing, DPK, and FDR had a significant positive effect, meanwhile NPF had a significant negative effect to the amount of financing provided by sharia banking. ROA and BOPO variables had no significant effect to the amount of financing provided. The research on BPRS conducted by Rahayu (2015) about the factors that affect the financing of BPRS with VECM method. The results showed that the shocks that occurred in the number of financing accounts, DPK, ROA, BOPO, ROE, and FDR were responded positively by BPRS financing. Meanwhile, the office network, CAR, NPF, and inflation were responded negatively by BPRS financing. In addition, Triana (2016) analyzed the factors affecting the profit sharing in BPRS in Indonesia using the same method as Rahayu (2015). The results indicated that the variables that affect significant long-term on BPRS financing are DPK, NPF, FDR, ROA, CAR, and ERP. Meanwhile BOPO variable had no significant effect.

Effendi (2013) conducted a study entitled The Role of Islamic Microfinance in Poverty Alleviation and Environmental Awareness in Pasuruan, East Java, Indonesia: A Comparative Study. The methods of analysis used were quantitative and qualitative. The results showed that sharia microfinance institutions had more significant impact in reducing poverty than conventional microfinance institutions, but had low effect on raising environmental awareness.

As for some things that distinguish this research with subsequent research, the variable used in this research is SMEs financing, meanwhile independent variable is divided into 2 . Internal variable from banking performance which is Third Party Fund, Financing to Deposit Ratio, Operational Cost Operational Income, Non Performing
Financing, Equivalent Rate Financing, and external variables of banking which is Bank Indonesia Sharia Certificates bonus, inflation, and Industrial Production Index. Then the object in this study is the SMEs financing distributed by the BPRS in Indonesia. This study as conducted from 2011-2016 by using monthly financial statements of BPRS in Indonesia.

\section{HYPOTHESES DEVELOPMENT}

According to Kasmir (2005) sources of funds obtained bank comes from private equity, loans from other institutions, and borrowing from the public. All funds collected from the public by the bank is called third party funds (DPK). DPK is the most important source of funding for the activities of the operations of a bank and is a measure of success if the bank is able to finance the operations from this source of funding. Search DPK from the wider community is relatively easier when compared with other sources. Search funds from these sources the most dominant and largest source of funding is the most relied upon by the bank with the amount reached 80-90 percent of all funds managed by the bank. The funds were sourced from the wider community it belongs easy to obtained the origin can provide for results or margin or free competitive and other attractive facilities. Based on previous research conducted by Rahayu (2015), about the factors that affect the financing of BPRS that DPK influential positive and significant. Based on the theory and previous research, first hypothesis of this research is:

$\mathrm{H}_{1}$ : third party funds (DPK) has significant positive effect on SMEs financing in BPRS in Indonesia

Financing to Deposit Ratio (FDR) is a comparison between the financing provided by the bank with the DPK successfully compiled by the Bank. FDR is the ratio of the banking liquidity. The 


\section{Jurnal Keuangan dan Perbankan | PERBANKAN}

Vol. 21, No. 3, Juli 2017: 498-514

liquidity ratio is the ratio of to measure the ability of a bank to meet short-term obligations at the time billed. In other words, it can pay back the disbursement of funds of depositors at the time billed as well as be able to fullfill the request credit have been proposed (Kasmir, 2012). This ratio is used to measure the extent to which loan funds are sourced from third party funds. High low this ratio indicates the level of liquidity the bank so the higher the number the FDR at the bank, meaning the bank is at a position of less liquid than the bank has a number of smaller ratio. The results of previous research conducted by Adzimatinur, Hartoyo, \& Wiliasih (2014) about the factors which influence the amount of financing of sharia banking in Indonesia shows that FDR effect significant positive. Based on the theory and previous research, second hypothesis of this research is:

$\mathrm{H}_{2}$ : financing to deposit ratio (FDR) has significant positive effect on SMEs financing in BPRS in Indonesia

Operating Income Operating Cost (BOPO) is calculation of efficiency of bank by means of comparing between operational costs with operating income. The smaller the ratio is then the better a bank, because it illustrates that operational costs incurred smaller than the operational income. According to the provisions of Bank Indonesia, the maximum limit of 90 percent is a BOPO for shows a good level of efficiency of the bank. Based on the theory, third hypothesis of this research is:

$\mathrm{H}_{3}$ : operational income operating cost (BOPO) has significant negative effect on SMEs financing in BPRS in Indonesia

The role of banking intermediation agencies are brought together as the funds and redistributes the funds to the community. The distribution of funds by Islamic banking is done in the form of an agreement between the bank and the cus- tomer that called with the financing. Islamic banks in this regard is Islamic Rural Bank will experiencing risk when finance. The risk is insolvency of the customer in restoring the financing have been given by the bank, or also known as troubled financing (Non Performing Financing). The risk is insolvency of the customer in restoring the financing have been given by the bank, or also known as troubled financing. According to Wangsawidjaja (2012), financing problematic occurred because bank credit planning, as well as integrity analyst credit is not good. In addition, the bank supervision after the credit is given in adequate and the amount of credit given less sufficient or excessive compared to the real needs. According to the circular letter BI No.17/19/DPUM 8 July 2015, NPF is the summation of the financing quality with less smoothly, doubt, and jammed the transmitted bank common. Bank Indonesia set a maximum ratio of NPF was 5 percent. Based on earlier research conducted by Mulianingtyas (2015) are researching about the factors which affect the volume of financing for the profit and loss sharing at Islamic banking in Indonesia, that the NPF may effect negatively to financing SMEs. Based on the theory and previous research, fourth hypothesis of this research is:

\section{$\mathrm{H}_{4}$ : non performing financing (NPF) has signifi- cant negative effect on SMEs financing in BPRS in Indonesia}

Equivalent rate is indicative of the level of remuneration of a planting Fundor gathering together the banking fund (Islamic Banking Statistics, 2015). The role of the equivalent rate is almost the same with interest on a conventional bank, give an idea how big the rate of return on investment. The difference, interest rates directly exchanged at the beginning of the contract before the investment happens, while equivalent rate calculated by the bank at the end of months after the investments that run get results. This rate 


\section{The Effect of Internal and External Factors of Banking to the Smes Financing for BPRS in Indonesia}

Jaenal Effendi, Nurkholis Yasmin

equivalents can be used to give an estimate to the customer how many equivalent bank rate the following month by looking at the equivalent rate in the past month. Equivalent rate on islamic banking comprises the equivalent rate of third party funds (ERDPK) and equivalent rate of financing (ERP). ERDPK is a level for results or margin or fee average of DPK consisting of sharia deposits and saving. This is ERDPK the rate for the profit and loss sharing to be paid by the banking to third parties. While ERP is the level for results/ margin/ average fee financing charged by the islamic banking to the debtor. Based on the theory, fifth hypothesis of this research is:

$\mathrm{H}_{5}$ : equivalent rate financing has significant positive effect on SMEs financing in BPRS in Indonesia

Based on Bank Indonesia Regulation (PBI) No.10/11/PBI/2008, Wadiah Bank Indonesia Certificates (SWBI) replaced by the Certificate of Indonesian Sharia Bank (SBIS). Sharia is converted into monetary instruments SBIS because of the lower SWBI return of the SBI interest rate so that the islamic bank assume that SWBI does not provide a competitive investment level. Up to this point the value fee SBIS refers to the interest rate a Certificate of Indonesian Bank (SBI). Certificate of Indonesian Sharia Bank (SBIS) also using shariah contract. The contract also constitutes a promise or commitment to grant wage certain over the achievement of results that are determined from a job, in this case islamic banks are considered already participating to help the task of monetary control in Bank Indonesia through the absorption of liquidity community and place them in the amount and period of time. Period of ownership SBIS are 1, 3, 6, and 9 months. Based on the theory, sixth hypothesis of this research is:

$\mathrm{H}_{6}$ : Bank Indonesia Sharia Certificate bonus has significant negative effect on SMEs financing in BPRS in Indonesia
Generally, inflation is often understood as a situation where in general the prices soared and the value of money experience decreased so that the purchasing power of money decreases. On a conventional bank, will put in place a system of interest as compensation for the fall in the purchasing power of money as long as the money is loaned. According to Mankiw (2007) if the value of inflation is higher than expected, it will cause a debtor to pay his debts with a smaller dollar value and will be detrimental to creditors. While on the side else, if the value of inflation is lower than expected, it would be the profit for the lender because the payment of the debt by the debtor that becomes larger. The higher the value of the inflation, it will be the greater uncertainty that will be faced by the creditor and the debtor. Based on the theory, seventh hypothesis of this research is: $\mathrm{H}_{7}$ : inflation has significant negative effect on SMEs financing in BPRS in Indonesia

Industrial Production Index (IPI) is a macroeconomic variables who can measure the performance of the economy (Mankiw, 2007). This index is calculated by looking at changes or compare quantum production month against the quantum of production the previous month. So the production index of the month running is a development of the production the previous month. The index of industrial production is considered more fully to explain the growth of economy when compared with the Gross Domestic Product (GDP). Index industrial production is based on the concept of value added which includes output physical sector of the entire production stage of manufacturing, mining, gas, and electricity. This index has historically represented the majority of total output fluctuations, though added value of the industrial sector is only part of the economy as a whole. Therefore, the change of these indicators will generally describe the changes of the economy as a whole. Increase economic 
growth, will generate a positive impact on performance of the economy include banking. Based on the theory, eight hypothesis of this research is:

$\mathrm{H}_{8}$ : industrial production index (IPI) has significant positive effect on SMEs financing in BPRS in Indonesia

\section{METHODS}

The type of data used in this study is secondary data. Secondary data is data which at the time of collection is not (not necessarily) to meet the needs which is faced. This study used monthly secondary data from January 2011-December 2016. The data were from the Sharia Banking Statistics published by the Financial Services Authority (SPSOJK), the Central Bureau of Statistics (BPS), the Ministry of Cooperatives and SMEs, and Bank Indonesia as well as various literatures such as books, journals, previous research, and electronic media.

Data analysis method used in this research is descriptive quantitative. Analysis tool used in this research is Vector Autoregression (VAR) method if data used stationary in the level of level, but if data used stationary in the first difference then continued with Vector Error Correction Model (VECM) method. The data is processed using software Eviews 8 and Microsoft Excel 2007.

According to Juanda \& Junaidi (2012) if the data used in the analysis is time series data, the Vector Autoregressive model (VAR) offers an alternative modeling as a way out. The VAR model is built with an approach that minimizes the theory with the aim of being able to capture the economic phenomenon well. The VAR model is referred to as a non-structural model or a non-theoretical model. This method has a credible and easy-tounderstand approach to data descriptions, forecasting, and policy analysis (Koop, 2013). The VAR equation generally can be written in the form as follows:
$y_{t}=A_{0}+A_{1} y_{t-1}+A_{2} y_{t-2}+\cdots+{ }_{p} y_{t-p}+e_{t}$

Note:

$y_{t}=$ vector size $(\mathrm{n} \times 1)$ containing $\mathrm{n}$ variables in a VAR model

$A_{0}=$ independent vector of intercept size $(n \times 1)$

$A_{t}=$ matrix coefficient/parameter size $(n \times n)$

$e_{t} \quad=$ error vector size $(n \times 1)$

VAR has 3 model forms, one of them is restricted VAR or VAR model which is restricted, also called Vector Error Correction Model (VECM) in Juanda \& Junaidi (2012). This restriction must be added because of the non-stationary data form in the level, but cointegrated. VECM will utilize the cointegration restriction information into its specifications. Therefore, VECM is also referred to as the VAR design for nonstationary series and has a cointegrated relationship. There is speed of adjustment from short to long term within VECM. The general equation of VECM is as follows:

$\Delta y_{t}=\mu 0_{x}+\mu 1_{x} t+\Pi_{x} y_{t-1}+\sum_{i=1}^{k-1} \Gamma_{x i} \Delta y_{t-i}+\varepsilon_{t}$

Note:

$\Delta y_{t}=$ vector containing the analyzed variable in research

$\mu 0_{\mathrm{x}}=$ intercept vector

$\mu 1_{x}=$ regression coefficient vector

$\mathrm{t}=$ time trend

$\Pi_{x}=\alpha_{x} \beta^{\prime}$ where $\beta^{\prime}$ containing longterm cointegration equation

$\mathrm{y}_{\mathrm{t}-1}=$ variabel in-level

$\Gamma_{\mathrm{ix}} \quad=$ regression coefficient matrix

$k-1=$ ordo VECM from VAR

$\varepsilon_{\mathrm{t}}=$ errorterm 


\section{The Effect of Internal and External Factors of Banking to the Smes Financing for BPRS in Indonesia \\ Jaenal Effendi, Nurkholis Yasmin}

\section{Data Stationerity Test}

Unit root test is the first step that must be done in processing time series data. The goal is to see the stationary data or not. The stationary data tends to be close to the average value and fluctuates around its average value. Non-stationary data can produce spurious regression, which is a regression that describes the relationship of 2 or more variables that seem statistically significant when in fact it is not (Gujarati, 2007). In this research, stationery test data using Phillips Pherron. In Phillips Pherron test (t-PP), if the value of $t-P P$ is smaller than its MacKinnon Critical Values, the stationary data is at a predetermined rate. It can also be seen from its probability value. If the data is stationary then VAR so the data can be used, but if it is not stationary then there are 2 choices, using VAR in the form of first difference or VECM. The presence of non-stationary variables increases the likelihood of cointegration between variables.

\section{Cointegration Test}

Cointegration test is intended to determine whether non-stationary variable which is cointegrated exist or does not exist. Gujarati (2007) explains in period series data (time series), it is possible that non-stationary variables have an equilibrium or stable (long-term) relationship between the two which is called as cointegrated. In 1987, this concept was first introduced by Engle and Granger as a linear combination of two or more non-stationary variables. The combination is known as cointegration equation or long-term equilibrium relationship between variables. There are several methods that can be used to perform cointegration tests, such as Eagle-Granger Cointegration Test, Johansen Cointegration Test, and Cointegration Regression Durbin-Watson Test. An equation is considered to have cointegration if the trace statistic value exceeds the critical value. After the cointegration equation is known, the Vector Error Correction Model (VECM) analysis can be performed.

\section{Impulse Response Function (IRF)}

IRF is a method used to determine the response of an endogenous variable to a particular shock. IRF is also used to measure the effect of a shock at a time to the innovation of endogenous variables in the future. Another purpose of IRF is to isolate a shock to be more specific, which means that shock can affect a variable. Shocks that can be known are only general non-specific shock.

\section{Forecast Error Variance Decomposition (FEVD)}

The FEVD method is characteristic of the dynamic structure of VAR/ VECM model. This method is intended to see the change of a variable indicated by the change in error variance influenced by other variables. The FEVD method can show the strength and weaknesse of a variable which affecting other long-term variables.

The big difference between error variance before and after the shock occurrence is that comes from itself or from other variables which can be determined by calculating the percentage of squares of k-phase error predictions from a variable due to innovation in other variables. The VECM model used in this research is:

$\left[\begin{array}{c}\Delta L n P U K M_{t} \\ \Delta L n D P K_{t} \\ \Delta F D R_{t} \\ \Delta B O P O_{t} \\ \Delta N P F_{t} \\ \Delta E R P_{t} \\ \Delta B S B I S_{t} \\ \Delta I N F_{t} \\ \Delta I P I_{t}\end{array}\right]=\left[\begin{array}{c}\alpha_{10} \\ \vdots \\ \alpha_{90}\end{array}\right]+\left[\begin{array}{ccc}\alpha_{11} & \cdots & \alpha_{19} \\ \vdots & \ddots & \vdots \\ \alpha_{91} & \cdots & \alpha_{99}\end{array}\right]\left[\begin{array}{c}\Delta L n P U K M_{t-1} \\ \Delta L n D P K_{t-1} \\ \Delta F D R_{t-1} \\ \Delta B O P O_{t-1} \\ \Delta N P F_{t-1} \\ \Delta E R P_{t-1} \\ \Delta B S B I S_{t-1} \\ \Delta I N F_{t-1} \\ \Delta I P I_{t-1}\end{array}\right]+\left[\begin{array}{c}e_{1 t} \\ \vdots \\ e_{9 t}\end{array}\right]$

Note:

LnPUKM $_{t}=$ SMEs financing in BPRS $t$-period (million rupiah) 


\begin{tabular}{|c|c|}
\hline LnDPK $_{t}$ & $\begin{aligned}= & \text { third party fund tperiod (million ru- } \\
& \text { piah) }\end{aligned}$ \\
\hline $\mathrm{FDR}_{\mathrm{t}}$ & $\begin{aligned}= & \text { financing deposit to ratiot-period } \\
& (\text { percent })\end{aligned}$ \\
\hline $\mathrm{BOPO}_{\mathrm{t}}$ & $\begin{aligned}= & \text { the ratio of operational income op- } \\
& \text { erating costt-period (percent) }\end{aligned}$ \\
\hline $\mathrm{NPF}_{\mathrm{t}}$ & $\begin{aligned}= & \text { non performing financing } \mathrm{t} \text {-period } \\
& (\text { percent })\end{aligned}$ \\
\hline $\mathrm{ERP}_{\mathrm{t}}$ & $\begin{aligned}= & \text { equivalent rate financing } \mathrm{t} \text {-period } \\
& (\text { percent })\end{aligned}$ \\
\hline
\end{tabular}
BSBIS $_{t}=$ bonus certificates of Bank Indone- sia Sharia t-period (percent)
$\mathrm{INF}_{\mathrm{t}} \quad=$ inflationt-period (percent)
IPI $_{\mathrm{t}}=$ industrial production index (index)

\section{RESULTS}

The effect of internal and external factors on SMEs financing provided by BPRS in Indonesia will go through several test stages. The test series consist of stationarity test, optimal hose test,

\section{Variables and Operational Definition}

Table 1. Variables and Operational Definition

\begin{tabular}{|c|c|c|}
\hline Name of Variables & Definition & Measurement \\
\hline $\begin{array}{l}\text { Financing of Small and Medium } \\
\text { Enterprises (smes) }\end{array}$ & $\begin{array}{l}\text { The amount of financing provided by BPRS to Small and } \\
\text { Medium Enterprises }\end{array}$ & Trillion rupiah unit \\
\hline Third Party Fund (DPK) & The amount of funds collected by BPRS & Trillion rupiah unit \\
\hline Financing to Deposit Ratio (FDR) & $\begin{array}{l}\text { Ratio of sharia financing to the total ofthrid party funds } \\
\text { in BPRS as a whole based on sharia banking statistics }\end{array}$ & Percentage unit \\
\hline $\begin{array}{l}\text { Operational Income Operating } \\
\text { Cost (BOPO) }\end{array}$ & $\begin{array}{l}\text { Calculation of bank efficiency by comparing operational } \\
\text { cost with operating income }\end{array}$ & Percentage unit \\
\hline Non Performing Financing (NPF) & $\begin{array}{l}\text { Description of financing quality measured by } \\
\text { comparison of the total of non-performing financing } \\
\text { with the total of financing. Non-performing financing is } \\
\text { the financing with substandard, doubtful and loss } \\
\text { qualities which is adjusted to the criteria of Bank } \\
\text { Indonesia Regulation Number } 8 / 21 / \text { PBI/ } 2006 \\
\text { concerning Quality Rating of Commercial Banks that is } \\
\text { conducting business activities based on sharia principles }\end{array}$ & Percentage unit \\
\hline Equivalent Rate of Financing (ERP) & $\begin{array}{l}\text { Rate of return/margin/fee of the total contract whose } \\
\text { value is the average of the profit sharing of total } \\
\text { financing contracts with the amount of expenses used }\end{array}$ & Percentage unit \\
\hline $\begin{array}{l}\text { Bonus Certificates of Bank } \\
\text { Indonesia Sharia (BSBIS) }\end{array}$ & $\begin{array}{l}\text { Monetary policy instrument that aims to overcome } \\
\text { liquidity difficulties in Shariabanking }\end{array}$ & Percentage unit \\
\hline Inflation & $\begin{array}{l}\text { A change from the increaseof the consumer price index } \\
\text { (CPI) of the current month against the previous month. } \\
\mathrm{CPI} \text { is an index that describes the average price change } \\
\text { of the package of goods and services consumed by } \\
\text { households within a certain time period used to } \\
\text { measure inflation. Current month inflation illustrates } \\
\text { the change in price escalation in the previous month }\end{array}$ & Percentage unit \\
\hline Industrial production Index (IPI) & $\begin{array}{l}\text { An illistration of economic growth seen from the change } \\
\text { or comparison of quantum production of current month } \\
\text { to quantum production in the previous month, so that } \\
\text { the current month production index is an illustration of } \\
\text { the previous month's production development }\end{array}$ & \\
\hline
\end{tabular}


Table 2. Stationarity Test

\begin{tabular}{lcccc}
\hline \multirow{2}{*}{ Variable } & \multicolumn{3}{c}{ Level } & \multicolumn{2}{c}{ First difference } \\
\cline { 2 - 5 } & PP-Statistic & t-Statistic 5 Percent & PP-Statistic & t-Statistic 5 Percent \\
\hline Ln PUKM & -1.349790 & -3.474363 & $\mathbf{- 6 . 8 8 7 4 3 3}$ & -3.475305 \\
LnDPK & -1.636226 & -3.474363 & $\mathbf{- 6 . 7 9 1 9 5 1}$ & -3.475305 \\
FDR & -2.239693 & -2.902953 & $\mathbf{- 6 . 1 7 7 5 9 4}$ & -2.903566 \\
BOPO & -2.312546 & -3.474363 & $\mathbf{- 1 1 . 4 7 8 3 8}$ & -3.475305 \\
NPF & $\mathbf{- 3 . 8 0 3 9 6 7}$ & -3.474363 & $\mathbf{- 1 1 . 1 5 1 8 1}$ & -3.475305 \\
ERP & -3.040785 & -3.474363 & $\mathbf{- 9 . 1 3 3 2 7 2}$ & -3.475305 \\
BSBIS & -1.773792 & -3.474363 & $\mathbf{- 5 . 1 6 1 8 4 6}$ & -3.475305 \\
INF & -1.834873 & -2.902953 & $\mathbf{- 5 . 9 8 9 8 2 9}$ & -2.903566 \\
IPI & $\mathbf{- 6 . 5 9 7 3 9 4}$ & -3.474363 & $\mathbf{- 3 7 . 4 5 5 7 1}$ & -3.475305 \\
\hline
\end{tabular}

VAR stability test, cointegration test, and longterm VECM model estimation test. After the test process is completed, the mechanism of each factor that affects BPRS in providing SMEs financing will be discussed.

\section{Stationarity Test}

Unit root test is the first step that must be done in processing time series data. The goal is to see stationary data or not. The stationary data tends to be close to the average value and fluctuates around its average value. Non-stationary data can produce spurious regression, which is a regression that describes the relationship of two or more variables that seem statistically significant when in fact it is not (Gujarati, 2007).

Stasionarity testing was used on Phillips Pherron (PP) test. The PP method will indicate whether or not there is root of the unit on all variables used by comparing the value of PP-statistic with the critical value of MacKinnon. The PP-statistic value which is smaller than the MacKinnon critical value indicates the data is stationary or has no unit root. Non-stationary data in the level of level will be tested further in the first difference level. The results showed stationary variables in the level were only NPF (Non Performing Financing) and IPI (Industrial Production Index). While in the first difference all variables were stationary.

\section{Optimal Hose Test}

Optimal lag testing (optimal hose) is useful to show how long the reaction of a variable to other variables and to eliminate the problem of autocorrelation in a VAR system. The optimal lag test in this study is based on criteria that have the smallest optimal lag (Koop, 2013). Optimal lag testing conducted in this study is based on Schwarz Criterion (SC) value with optimal lag 1.

Table 3. Optimal Hose Test

\begin{tabular}{cc}
\hline lag & Schwarz Criterion (SC) \\
\hline 0 & 20.91281 \\
1 & $\mathbf{8 . 2 1 9 0 2 3}$ \\
2 & 11.26109 \\
3 & 13.79534 \\
4 & 15.30175 \\
5 & 16.28589 \\
6 & 10.79055 \\
\hline
\end{tabular}

\section{Stability Var Test}

The next step to do is to test the stability of VAR or VAR stability condition check. This test is performed to calculate the roots of polynomial function or known as roots of characteristic polynomial. The VAR stability test is performed by calculating the roots of the polynomial function. The VAR model is said to be stable, if all the roots of the polynomial function are in the circle unit or if the absolute value is less than one so that the IRF and FEVD performed are considered valid 


\section{Jurnal Keuangan dan Perbankan | PERBANKAN}

Vol. 21, No. 3, Juli 2017: 498- 514

(Juanda \& Junaidi, 2012). The modulus value of the SMEs financing model in this study was in the range of $0.033163-0.990899$. Based on the results of testing the stability of the VAR model, it can be concluded that the VAR system was stable because all roots are in the unit circle or have a modulus value less than one.

\section{Cointegration Test}

Cointegration test is intended to determine whether non-stationary variable which is cointegrated exist or does not exist. Gujarati (2007) explained in period series data (time series), it is possible that non-stationary variables have an equilibrium or stable (long-term) relationship between the two which is called cointegrated. The cointegration testing criteria in this study is based on trace statistic value. If the value of trace statistic is greater than the critical 5 percent value, then the alternative hypothesis which states the number of cointegration is accepted, so the number of cointegrated equations in the system is known. Cointegration testing is performed using the optimal interval in accordance with the previous test.

The results showed that there were 3 cointegration rank at the real level 5 percent used. It means that there are multivariate long-term linear equation contained in the model.

Table 4. Cointegration Test

\begin{tabular}{lccccccc}
\hline & $\mathbf{H}_{\mathbf{0}}$ & $\mathbf{R}=\mathbf{0}$ & $\mathbf{R} \leq \mathbf{1}$ & $\mathbf{R} \leq \mathbf{2}$ & $\mathbf{R} \leq \mathbf{3}$ & $\mathbf{R} \leq \mathbf{4}$ & $\mathbf{R} \leq \mathbf{5}$ \\
\hline & $\mathbf{H}_{\mathbf{1}}$ & $\mathbf{R} \geq \mathbf{1}$ & $\mathbf{R} \geq \mathbf{2}$ & $\mathbf{R} \geq \mathbf{3}$ & $\mathbf{R} \geq \mathbf{4}$ & $\mathbf{R} \geq \mathbf{5}$ & $\mathbf{R} \geq \mathbf{6}$ \\
\hline Trace statistic & & $\mathbf{2 3 3 . 7 9}$ & $\mathbf{1 7 1 . 1 4}$ & $\mathbf{1 1 8 . 4 5}$ & 77.09 & 45.80 & 30.04 \\
Critical value & & 179.50 & 143.66 & 111.78 & 83.93 & 60.06 & 40.17 \\
\hline
\end{tabular}

Table 5. Result of VECM Estimation

\begin{tabular}{lrr}
\hline \multicolumn{1}{c}{ Variabel } & Short Term & t-Statistic \\
\hline CointEq1 & Koefisien & 0.19094 \\
D(LNPUKM(-1)) & 0.008492 & -0.03692 \\
D(LNDPK(-1)) & -0.007704 & $3.02642^{*}$ \\
D(FDR(-1)) & 0.879241 & $2.62699^{*}$ \\
D(BOPO(-1)) & 0.005880 & 0.25008 \\
D(NPF(-1)) & 0.000432 & 1.07035 \\
D(ERP(-1)) & 0.005826 & 0.15635 \\
D(BSBIS(-1)) & 0.000413 & 1.20307 \\
D(INF(-1)) & 0.010112 & -0.76913 \\
D(IPI(-1)) & -0.002415 & -0.47446 \\
\hline \multicolumn{1}{c}{ Variabel } & -0.000308 & Long term \\
\hline LNDPK(-1) & Koefisien & $-89.3293^{*}$ \\
FDR(-1) & 0.932981 & $-7.26491^{*}$ \\
BOPO(-1) & 0.009509 & 1.27093 \\
NPF(-1) & -0.003270 & $5.30885^{*}$ \\
ERP(-1) & -0.058523 & $4.09034^{*}$ \\
BSBIS(-1) & -0.021283 & $3.35695^{*}$ \\
INF(-1) & -0.027941 & $-4.83160^{*}$ \\
IPI(-1) & 0.023216 & $-7.34100^{*}$ \\
\hline
\end{tabular}




\section{The Effect of Internal and External Factors of Banking to the Smes Financing for BPRS in Indonesia}

Jaenal Effendi, Nurkholis Yasmin

\section{The Factors Affecting the Financing of Small and Medium Enterprises}

The result of VECM estimation test in Table 5 showed the relationship of short-term and longterm variables of SMEs financing. This research used significance with 5 percent real levelthat is tADF for critical value 5 percent equal to 1.965 . It means that it does not accept $\mathrm{H}_{0}$ if the absolute value of $t$-statistic is greater than the $t-A D F$ value then the variable has a significant effect.

Table 5 showed the results of VECM estimation in short and long terms of another variable that is not significant in the short-term indicated that a variable reacting to other variables requires time that generally occured in the longterm. All independent variables were significant in the long-term.

\section{DISCUSSION}

\section{The Effect of Third Party Funds}

Third Party Funds variable had a significant positive effect on total of SMEs financing provided by BPRS in the long-term. Each 1 percent increase in DPK so that it will increase the SMEs financing by 0.932981 percent with the assumption that other variables are remain. DPK is the main source of funds for financing, the greater the DPK that can be collected by the bank, the funding capabilities provided by the larger bank so that SMEs financing will increase.

\section{The Effect of Financing to Deposit Ratio}

The FDR variable had a significant effect on SMEs financing in the long-term. When FDR increase by 1 percent, it will escalate the increase in SMEs financing to 0.009509 percent with the assumption of other variables are remain. FDR is the ratio of financing and DPK, where the increase of FDR is caused by more financing distributed by the bank. This condition occurs because sharia banking can maintain the needs of funds obtained from third parties well, so that the bank always has a flow of funds that can be utilized to carry out financing activities.

\section{The Effect of Operational Cost Operational Income}

Operational Cost Operational Incomevariable (BOPO) had a negative but insignificant effect on SMEs financing provided by BPRS. This is in accordance with the research conducted by Triana (2016) on the factors that affect the profit sharing financing in BPRS in Indonesia, that the long-term BOPO variable had no significant effect. $\mathrm{BOPO}$ is a ratio that describes the level of bank profitability. This result indicated that the source of funds distributedfor financing come from third party funds and bank efficiency leveldid not significantly affect the distribution of SMEs financing.

\section{The Effect of Non Performing Financing}

NPF variable had a significant negative effect to the total SMEs financing in the amount of 0.058523 , which means that if there is a 1 percent increase of NPF it will reduce the SMEs financing by 0.058523 percent with the assumption that other variables are remain. NPF is a problematic financing so that the higher the problem of financing, it will reduce the amount of financing itself. The reason is when there is problematic financing, sharia banking funds cannot be turned from one customer to another customer. Higher troubled financing causes banks to have to set up larger removal funds that could lower the bank's interest to distribut funds through financing.

\section{The Effect of Equivalent Rate of Financing}

ERP variable had a significant negative effect on SMEs financing in the amount of 0.021283 . If there is 1 percent increase in ERP, it will reduce 
the SMEs financing by 0.021283 percent with the ceteris paribus assumption. This is not in accordance with the initial hypothesis that ERP had a significant positive effect on SMEs financing. However, the results of this study is similar to the research conducted by Zulhidia (2015) on the factors that affect the amount of financing of the processing industry sector in BPRS in Indonesia. This study was similar to the research conducted by Septindo (2016). SMEs financing in BPRS is dominated by murabahah contract financing which in principle sale and purchase murabahah income obtained by the bank is fixed because the margin set by the bank against the debtor has been determined at the beginning. In contrast to financing with the profit sharing agreement of mudharabah and musharakah which the profit sharing depends on the profit/ loss of the debtor. Therefore, when there is an increase of equivalent rate of financing dominated by murabahah financing, the margin that must be paid by the customer in this case is the SMEs enterprenuers will be larger so that the financing customer will look for other financing alternatives such as conventional bank credit so that SMEs financing will decrease.

\section{The Effect of Indonesian Sharia Bank'sCertificates Bonus}

BSBIS variable had significant negative effect to SMEs financing in the amount of 0.027941 with ceteris paribus assumption. This result showed that every 1 percent increase of BSBIS will decrease SMEs financing by 0.027941 percent. This is in accordance with the initial hypothesis of the study and also with the research conducted by Ramadhan \& Beik (2013) and Kusumawati (2013) that BSBIS had a significant negative effect on SMEs financing. It happens because when the SBIS bonus increases, it will increase the placement of sharia banking funds including BPRS in the form of Certificate of Indonesian Sharia Bank (SBIS). BPRS will be more interested in allocating funds to SBIS be- cause it promises high returns and has a lower risk than providing financing to more risky SMEs. It will reduce the distribution of BPRS funds to SMEs financing.

\section{The Effect of Inflation}

Inflation variable in long-term had a significant positive effect to SMEs financing with coefficient of 0.023216 . It means that if inflation increases by 1 percent then SMEs financing will increase by 0.023216 percent with ceteris paribus assumption. This result is not in accordance with the initial hypothesis that inflation has a negative effect on SMEs financing. Based on the development, it was known that the average rate of inflation during the observation period that occurred in Indonesia from 2011-2016 is 5.53 percent. The inflation rate was still in single digits so it has not affected the financing activities undertaken by the BPRS for SMEs. In addition, sharia banks in this case including BPRS have different characteristics with conventional financial institutions that depend on inflation-affected interest rates. BPRS use profit sharing system so that inflation did not have a big effect on sharia banking product which is in this case is SMEs financing.

\section{The Effect of Industrial Production Index}

IPI variable in the long-term had a significant positive effect on SMEs financing with a coefficient of 0.013741 . It means that when a 1 percent increase in IPI, it will be responded by an increase in SMEs financing of 0.013741 percent with ceteris paribus assumption. The results of this study are in accordance with the initial hypothesis that IPI has a significant positive effect on SME financing. These results are also in accordance with the research conducted by Zulhidia (2015). The reason is that when economic growth improves which is reflected by the increase of industrial production index growth, it will support the performance of 
sharia banking, including the distribution of SMEs financing that drives the real sector.

\section{SMEs Financing Response to Internal and External Variable Shocks}

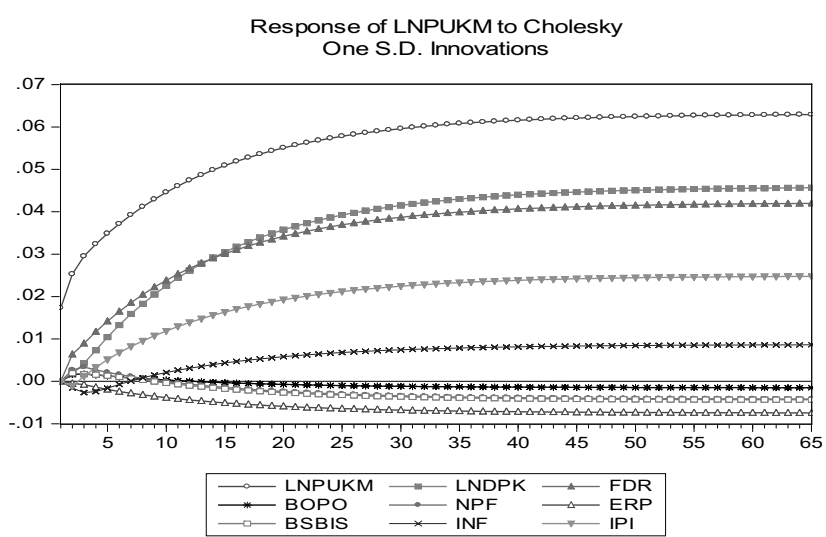

Figure 1. Impulse Response Function (IRF)

The Impulse Response Function (IRF) analysis in this study is intended to observe the response which is given by SME financing in the current period and forecasting the condition of SMEs financing in case of shocks on internal and external factors during 65 months of observation. The shocks on DPK variable in the first month appear to have not been responded by SMEs financing. In the second month, SMEs financing showed a positive response of 0.1702 percent. SMEs financing response began to reach a stable point in the 27 th month with a value of 4.0239 percent until the final month of observation. FDR variable shocks have not been responded by SMEs financing in the first month. In the second month, SMEs financing responded positively to FDR shocks of 0.6363 percent and continued to increase until the 35th month in the amount of 3.9880 percent. SMEs financing response to FDR shocks showed a stable response in the 36th month in the amount of 4.1971 percent.
The BOPO variable shock in the first month of observation has not shown any response by SMEs financing. In the second month BOPO has shown a positive response and fluctuated until the 12th month of observation. The negative response was shown by SMEs financing from the 13th period and reached a stable point in the 26th observation period in the amount of -0.1038 percent. Shock on NPF variable of one standard deviation in the first month have not been responded by SMEs financing. Astable response of SMEs financing toward shock on NPF began to occur in the 24th month of observation in the amount of -0.2906 percent. Shock on ERP variable has not been responded by SMEs financing in the first period of observation. In the second period, shockis started negatively responsed by SMEs financing of -0.0504 percent. This negative response is increasing to achieve long-term stability in the 29th period with a value of -0.6729 percent.

Shock in the BSBIS variable by one standard deviation in the first month has not been responded by SMEs financing. The 10th period until the end of the observation which is the 65th period of negative response gradually increased and between periods reached a stable point in the 30th observation period with a value of -0.3621 percent. Shock on inflation in the first period has not been responded by SMEs financing. The positive response of SMEs financing occurred in the seventh observation period in the amount of 0.0098 percent. A stable response of SMEs financing occurred in the 27th month in the amountof 0.7084 percent. The same SMEs financing response occurred in the first month in response to IPI shock. Financing experienced a negative response only in the second month in the amount of -0.1172 percent. The next period, the third month until the end of observation of SMEs financing responded positively to reach a stable point in the 21st month in the amount of 2.0111 percent. 


\section{Contribution of Internal and External Variables in Explaining Diversity of SMEs}

\section{Financing}

Analysis of Forecast Error Variance Decomposition (FEVD) in this study aims to explain the contribution of each internal and external variables in explaining the diversity of SMEs financing to BPRS in Indonesia. In the first month, the diversity of SMEs financing is only 100 percent influenced by the SMEs financing itself. SMEs financing that is affected by other variable shocks is only in response in the second period. The SMEs financing variables appear to be affected by the shocks of other variables in the second month, where SMEs financing provides 93.8664 percent of diversity. Meanwhile the FDR is in the second order in the amount of 4.0463 percent, then continue with the NPF variable of 0.7402 percent. Then the other variables are explained in smaller proportion by BSBIS of 0.3725 percent, DPK of 0.2896 percent, BOPO of 0.2637 percent, inflation of 0.2584 percent, IPI of 0.1372 percent, and ERP of 0.0254 percent.

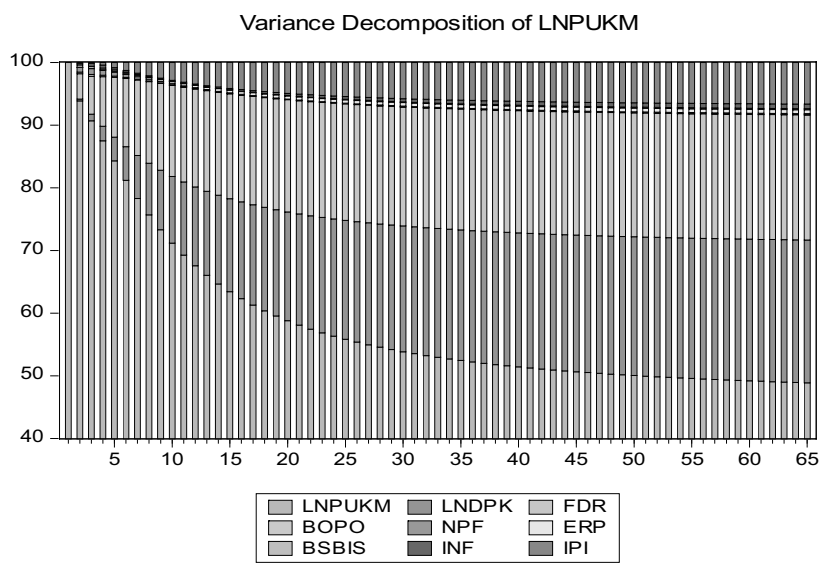

Figure 2. Forecast Error Variance Decomposition (FEVD)

At the end of the observation, the 65th period of the most dominant variable explaining the SMEs financing fluctuations in a row is the SMEs financing itself, but the contribution was smaller than the previous period of 48.8790 percent. The other 3 major contributions consisted of 2 internal variables and 1 external variable in explaining the diversity of SMEs financing which is Third Party Funds, Financing to Deposit Ratio, and Industrial Production Index of 22.7694 percent, 19.9877 percent, and 6.6512 percent. Then the variables that were not too influential on SMEs financing was the inflation of 0.7344 percent, ERP of 0.6108 percent, BSBIS of 0.1785 percent, NPF of 0.1663 percent, and the last is BOPO of 0.0222 percent.

\section{CONCLUSION AND SUGGESTIONS}

\section{Conclusion}

Based on the research that has been done, it can be concluded several things as follows: (1) internal variable (bank performance) and external (sharia monetary instrument and macroeconomic condition) which affected SMEs financing are Third Party Fund, Financing to Deposit Ratio, Non Performing Financing, Equivalent rate of financing, Inflation SBIS Bonus, and IPI. Meanwhile the variable that had no significant effect on SMEs financing was Operational Cost of Operational Income. The DPK, FDR, inflation, and IPI variables had a significant positive effect on SMEs financing. Meanwhile the ERP, NPF, and BSBIS variables had a significant negative affect to the SMEs financing; (2) based on the Impulse Response Function (IRF) result, the SMEs financing response to internal variable shock is quickly stabilized in the case of Non Performing Financing variable shock occurring in the 24th month of observation, while the SME financing response to external variable shocks is rapidly stabilized in the event of shocks On the Industrial Production Index variablein the 21st period; and (3) based on Forecast Error Variance Decomposition (FEVD) result, the contribution of the 3 largest internal and external variables after SME financing itself in explaining the diversity of SMEs financing is the total of DPK, FDR, and IPI. 


\section{The Effect of Internal and External Factors of Banking to the Smes Financing for BPRS in Indonesia}

Jaenal Effendi, Nurkholis Yasmin

\section{Suggestions}

As for suggestions that could be given related to this research for further research are: (1) BPRS should continue to increase the number of DPK, because based on FEVD result, internal variable of banking, which is DPK gives big contribution to SMEs financing. Based on the estimation result of VECM, it is known that NPF had a significant negative effect on SME financing. BPRS should be able to control the NPF's value by monitoring the financing distributed and pay attention to the other influential variables in order to increase SMEs financing. Besides doing the monitoring BPRS should regularly conduct business assistance, training, and guidance on SMEs; (2) based on the IRF result, it is found that the SMEs financing response is quickly stabilized when there is a shock to the NPF variable. This study recommends that BPRS should prepare Provision for Earning Assets Losses (PPAP) in the amount that stipulated in the Financial Services Authority Regulation No.5/POJK3/2015 regarding minimum capital requirement and minimum capital requirement of rural banks for up to 24 months. It is intended to reduce the risk of problem financing faced by BPRS in Indonesia; and (3) further research can increase the observation period and expand the scope of the research by classifying BPRS by region so that the results of the research are more varied. In addition, it can also add other variables such as NPF of SMEs financing group to BPRS in order to get more accurate results.

\section{REFERENCES}

Adzimatinur, F., Hartoyo, S., \& Wiliasih, R. 2014. Factors Affecting the Amount of Financing Islamic Banking in Indonesia. Journal Al-Muzara'ah, 3(2): 106122.

Ascarya \& Yumanita, D. 2014. Mencari Solusi Rendahnya Pembiayaan Bagi Hasil di Perbankan Syariah. Proceedings National Seminar LPPI.
Beik, I.S. \& Arsyianti, L.D. 2015. Ekonomi Pembangunan Syariah. Bogor: IPB Press.

Effendi J. 2013. The Role of Islamic Microfinance in Poverty Alleviation and Environment Awareness in Pasuruan, East Java, Indonesia: A Comparative Study. Dissertation. University School of Science.

Financial Services Authority. 2011. Islamic Banking Statistics January-December 2011. http:/ / www.ojk.go.id. Accessed: December 5, 2016.

Financial Services Authority. 2012. Islamic Banking Statistics January-December 2012. http:/ / www.ojk.go.id. Accessed: December 5, 2016.

Financial Services Authority. 2013. Islamic Banking Statistics January-December 2013. http:/ / www.ojk.go.id. Accessed: December 5, 2016.

Financial Services Authority. 2014. Islamic Banking Statistics January-December 2014. http:/ / www.ojk.go.id. Accessed: December 5, 2016.

Financial Services Authority. 2015. Islamic Banking Statistics January-December 2015. http:/ / www.ojk.go.id. Accessed December 5, 2016.

Financial Services Authority. 2016. Islamic Banking Statistics January-December 2016. http:/ / www.ojk.go.id. Accessed: December 5, 2016.

Gujarati, D. 2007. Dasar-dasar Ekonometrika. Jakarta: Erlangga.

Juanda, B. \& Junaidi. 2012. Ekonometrika Deret Waktu: Teori dan Aplikasi. Bogor: IPB Press.

Kara, M. 2013. Kontribusi Pembiayaan Perbankan Syariah terhadap Pengembangan Usaha Mikro Kecil dan Menengah. Jurnal Ilmu Syariah dan Hukum, 47(1): 269-302.

Kasmir. 2005. Pemasaran Bank. Jakarta: Kencana.

Kasmir. 2012. Manajemen Perbankan (Edisi Revisi). Jakarta: Raja Grafindo.

Kementerian Perdagangan. 2013. Analisis Peran Lembaga Pembiayaan dalam Pengembangan UMKM.

Kusumawati, N.N. 2013. Islamic Banking Financing Analysis on Construction Sector in Indonesia. Jurnal Al-Muzara'ah, 1(2): 191-203. 


\section{Jurnal Keuangan dan Perbankan | PERBANKAN}

Vol. 21, No. 3, Juli 2017: 498-514

Koop, G. 2013. Analysis of Economic Data. United Kingdom: John Wiley \& Sons, Ltd.

Mardani, Y. 2016. Analisis Faktor-faktor yang Memengaruhi Pembiayaan untuk Sektor UMKM di Indonesia. Dissertation. Bogor Agricultural University.

Mankiw, N.G. 2007. Makroekonomi. Edisi Keenam. Jakarta: Erlangga.

Ministry of Cooperatives and Small and Medium Enterprises. 2017. Sandingan data UMKM tahun 20102015.

Ministry of Religious Affairs. 2013. The Holy Quran and its Translation.

Mulianingtyas, D. 2015. Analisis Faktor-faktor yang Memengaruhi Volume Pembiayaan Bagi Hasil Bank Umum Syariah di Indonesia (Periode 20092013). Dissertation. Bogor Agricultural University.

Partomo, T.S. \& Soejoedono, A.R. 2002. Ekonomi Skala Kecil/ Menengah dan Koperasi. Jakarta: Ghalia Indonesia.

Rahayu, D.N. 2015. Faktor-faktor yang Memengaruhi Pembiayaan pada Bank Pembiayaan Rakyat Syariah. Dissertation. Bogor Agricultural University.
Ramadhan, M.M. \& Beik, I.S. 2013. Analysis of the Impact of Islamic and Conventional Monetary Instruments towards Financing of Micro, Small, and Medium Enterprises Sector in Indonesia. Journal Al-Muzara'ah, 1(2): 175-189.

Septindo, D. 2016. Analisis Pengaruh Instrumen Moneter Syariah dan Konvensional terhadap Penyaluran Dana ke Sektor Pertanian di Indonesia. Dissertation. Bogor Agricultural University.

Tambunan. 2009. UMKM di Indonesia. Jakarta: Ghalia Indonesia.

The Central Bureau of Statistics. 2017. Monthly Production Index.

Triana, A. 2016. Analisis Faktor-faktor yang Memengaruhi Pembiayaan Bagi Hasil pada BPRS di Indonesia. Dissertation. Bogor Agricultural University.

Wangsawidjaja, A. 2012. Pembiayaan Bank Syariah. Jakarta: PT. Gramedia Pustaka Utama.

Zulhidia, G. 2015. Faktor-faktor yang Memengaruhi Besaran Pembiayaan Sektor Industri Pengolahan pada Bank Pembiayaan Rakyat Syariah di Indonesia. Dissertation. Bogor Agricultural University. 